\title{
IMPORTANCE of SOLAR LIGHTING SYSTEMS in TERMS of ENVIRONMENTAL POLLUTION
}

\author{
Y. Oğuz, M. Şahin, E. Şahin and Y. Güven
}

\begin{abstract}
One of the alternatives to fossil fuels is the solar energy to produce electricity parallel with today's rapidly advancing technology. Solar energy is the most important and the cleanest energy source that it can be used in almost every field. Lighting systems come at the first of these areas. Almost $\% 25$ of produced electricity is being consumed for lighting in all over the world. Therefore, using alternative energy for lighting systems has become inevitable. For example, usage of alternative energy for lighting in the local parks, gardens and streets, longdistance highways and roads have become widespread quickly. Despite there is a transmission cost in addition to production cost in power plants, solar power systems have no transmission cost so usage of them are growing rapidly. However, it should be considered more seriously that component of solar power system must be chosen recyclable from production throughout operation. It is obvious that the usage of solar power system is inevitable when environmental effects of thermal power plant are being considered. Therefore usage of the solar energy should be expanded, especially in street, highway, park and garden lighting, traffic signals and remote area lighting system. Examples of these applications around the world should be encouraged to use in our country.

In this sense, this study has provided information about solar lighting systems and their new technology. Furthermore, an example of the integration the solar energy within a city lighting system has been investigated.
\end{abstract}

Index Terms-Solar Energy, Solar Lighting, Environmental Pollution, Renewable Energy

\section{INTRODUCTION}

$\mathrm{I}_{\mathrm{b}}^{\mathrm{N}}$ $\mathrm{N}$ recent years, renewable energy sources draw attention because of environmental impact of fossil fuels and their ongoing depletion day by day [1]. Sun is the most important energy source for our planet. Solar energy is an alternative to fossil fuels due to its clean and environmental friendly characteristic.

Y. Ŏguz, Afyon Kocatepe University, Electrical and Electronics and Engineering, Afyon, Turkey, (e-mail: yukseloguz@aku.edu.tr).

M. Şahin, Erzincan University, Electrical and Electronics and Engineering, Erzincan, Turkey, (e-mail: mustafasahin@erzincan.edu.tr).

Y. Guven, Kirklareli University, Technical Science Vocational School, Kirklareli, Turkey, (e-mail: yilmaz.guven@klu.edu.tr).
The solar radiation energy falling on earth in a year is about 160 times more than the earth's fossil fuels potential determined so far [2]. In addition, it is 15000 times more than fossil, nuclear and hydroelectric energy combined which are being produced on earth every year. From this point of view, maintaining of the solar energy is not a problem. The real problem is to convert the solar energy into an energy type that can be used for human activities in most effective way [3]. Production of electrical energy is mostly utilising the burning of fossil fuels like coal. However, the burning of fossil fuels emerges carbon dioxide, ash and some other waste. These wastes have several adverse impacts for the environment. Photovoltaic cells are leading alternative energy production method with no polluting effect [4-5].

It is necessary to extend the usage of solar energy as an alternative energy source to meet the growing energy demand all over the world [6-7]. Turkey is fortunate in the sense of solar energy potential with its geographical location compared to many other countries. According to a study conducted by EIE, based on measurements of State Meteorology Affairs General Directorate between 1966 and 1982, it has been found that annual sunshine duration of Turkey is 2640 hours (7,2 hours daily) and average total radiation intensity is $1311 \mathrm{kWh}$ per square meter in a year. [8]. Electrical energy derived from solar energy can run all systems which are being powered by main grid with the help of appropriate hardware. The aim of this study is to emphasize the importance of solar energy as an alternative to fossil fuels for lighting systems in terms of environmental pollution.

\section{A. Integration of Lighting System and Solar Energy}

The most important method to obtain electricity from solar energy is solar cells; they are also known as photovoltaic systems. It requires higher technology and more money to obtain electricity from solar energy. However, increasing environmental awareness has intensified efforts to use this method. Many studies have been occurred to produce electricity more efficiently with the invention of photovoltaic cells in 1959. Photovoltaic technology has made great progress in the past 50 years [9]. Systems that can provide electricity for 15000 homes were produced in 1990 . 
Photovoltaic cells are formed by combining two different semiconductor materials. These materials are usually made of silicone and they can generate electricity in each case of sun. So they can continue to generate electricity by emitting the radiation of sun in even cloudy weather. The most important features and advantages of photovoltaic cells are that they are reliable and they need little maintenance. They consist of four main parts as listed below.

Parts of the Photovoltaic system:

$>$ Solar Panel: Consist of Mono-crystalline cells and it produces the electricity.

$>$ Battery: The unit that stores the energy.

$>$ Invertors: The part allows home appliances to use the electricity produced by solar panels.

$>$ Regulator: The part that secures the system [9].

LED (Light Emitting Diode) is a semi-conductor, light emitting electronic circuit element. LEDs have low energy consumption, long life, durability, small size, quick response and many other advantage compare to traditional light sources. Cost of LED units is dwindling in parallel to the technological development so they can be used in lighting applications widely. It is observed that they are being used in tunnels, facades, sport area, industry as much as traditional street illumination. Integration of LEDs within new application in European countries has reached 50\%-70\% beyond the optimistic estimations [10].

According to the data provided by Ministry of Energy and Natural Resources in 2014, there are about 17 million street lamps in Turkey. This number has a $2.5 \%$ share of total consumed electricity and cost an annual amount of 288 million U.S. dollar. Again according to ministry's statistics, if these street lights replaced with LEDs, $75 \%$ saving would be achieve [11]. LEDs produce more light flux per watt than standard incandescent lamps produce. As we know the vast majority of energy used by standard bulbs is used as thermal effect. However, the thermal effect of the LEDs is greatly reduced and they have long uptime. Today, $3 \mathrm{~W}$ power LEDs can produce $231 \mathrm{~lm}$ per watt theoretically. Different lamps used in photovoltaic lighting application are given in Table 1. The value of light in lumen per consumed watt shows the superiority of LEDs [10].

TABLE I

THE LAMPS USED IN PHOTOVOLTAIC LIGHTING APPLICATIONS

\begin{tabular}{|c|c|}
\hline Lamp Types & $\begin{array}{c}\text { Light per-watt } \\
\text { (Lumen/Watt) }\end{array}$ \\
\hline Tungsten lamps & $6-10$ \\
\hline Halogen lamps & $16-22$ \\
\hline Compact fluorescent lamps & $30-60$ \\
\hline Fluorescent lamps & $46-95$ \\
\hline Gas discharge lamps & $55-125$ \\
\hline LED lamps & $60-132$ \\
\hline
\end{tabular}

Along with the raising environmental awareness, usage of solar powered for outdoor lighting systems is increasing while lighting systems are moving away from traditional methods. Solar lighting systems perform outstanding results for required parameters. They are also economic and efficient [12]. Solar panels are being used for these systems to produce individual electrical energy.

Solar street lighting systems have a wide range of application area. They are not only used in the street but also airports, harbours, docks, parks, gardens, road and highways. They are both environmental friendly and cost-effective. A solar street illumination system is composed of a solar panel, a group of batteries, a charge controller, sensors and lighting units (LED lamps). There might be a wind turbine additionally.

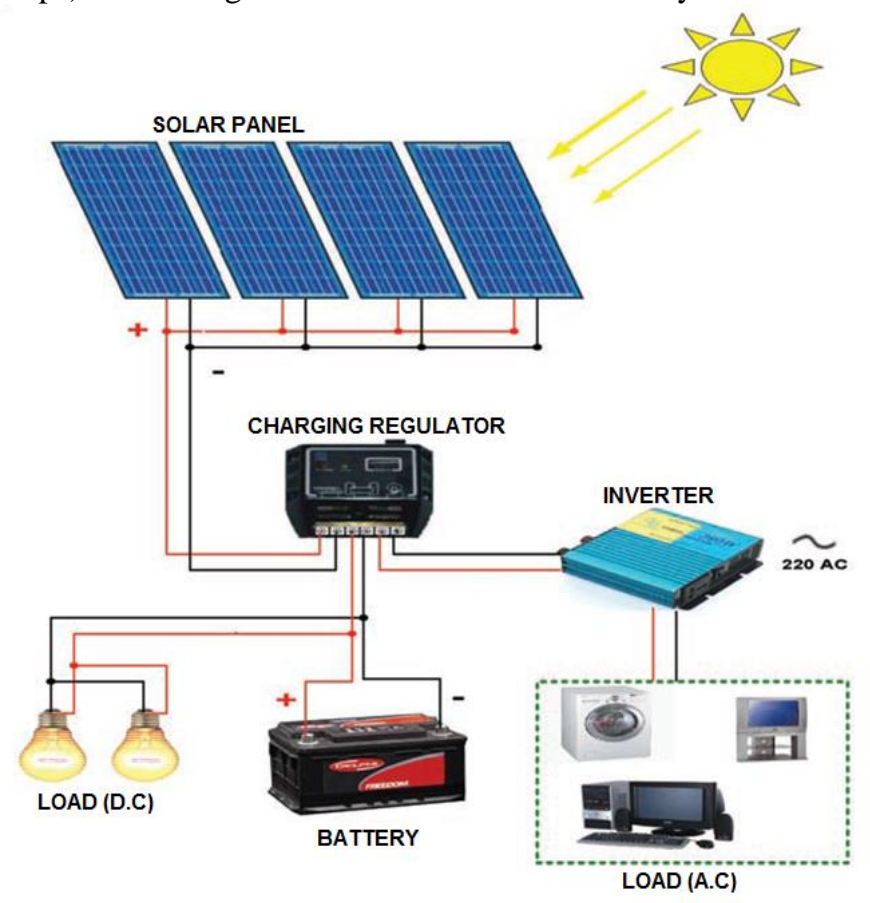

Fig 1. Basic parts of a solar street illumination system [13].

LED lighting armatures are optimized for thermal and photometric performance to achieve different illumination level. Thereby, the systems can be integrated to an automation system for different application and illumination levels. This can reduce the energy consumption between $50 \%$ and $80 \%$ [14]. All of these are the first and the most important step towards the concept of smart cities [15].

Typical applications that use Solar Lighting System are follows:

- Park and gardens,

- Urban streets and roads,

- Intercity highway and roads,

- Hotels, resorts and harbors,

- Ambient lighting of homes that is away from residential areas,

- Earthquakes and weather observation stations,

- Warning Systems and the traffic lamps, 
can be listed as application area of the solar lighting systems [16]. The followings specify the advantages of solar lighting system with power-LED:

- It is environmental friendly, it has low heat and light pollution.

- It has long lifetime and low cost.

- It does not strain eyes with high density, brightness and contrast.

- Consumes 10 times less energy than standard lighting systems.

- It gets instant access to the actual brightness and it is efficient.

- It is maintenance-free and it has a plug-and-play capability.

- $\quad$ There is no need to wiring.

- It has zero carbon dioxide emissions.

- It has resistant to shocks and physical impacts.

- It does not generate electromagnetic waves or interference signals and it does not contain heavy metal within [17].

\section{THEORETICAL GROUND}

The aim of this study is to provide 1072 watts electrical energy for two laboratories from solar-wind hybrid power generation system in the climate condition of Afyonkarahisar. To achieve this, a hybrid power generation system, consisting of three $190 \mathrm{~W} 24 \mathrm{~V}$ mono-crystalline solar panels and $600 \mathrm{~W}$ 3 phase permanent magnet synchronous generator (PMSG) that can rotate $360^{\circ}$ according to the direction of the wind, have been established. At the same time, six of 100Ah 12V deep cycle gel batteries have been installed to store unused electric energy for continuity of renewable energy system. The general view of the solar-wind hybrid power generation system with battery support is shown in Figure 2. The charge control unit is regulating the produced electrical energy to recharge the batteries. The amount of generated energy is being recoded through charging control unit with the help of a computer in every 10 second. The stored energy is being converted to A.C. by $3 \mathrm{~kW}$ sine wave inverter for supplying our loads [18].

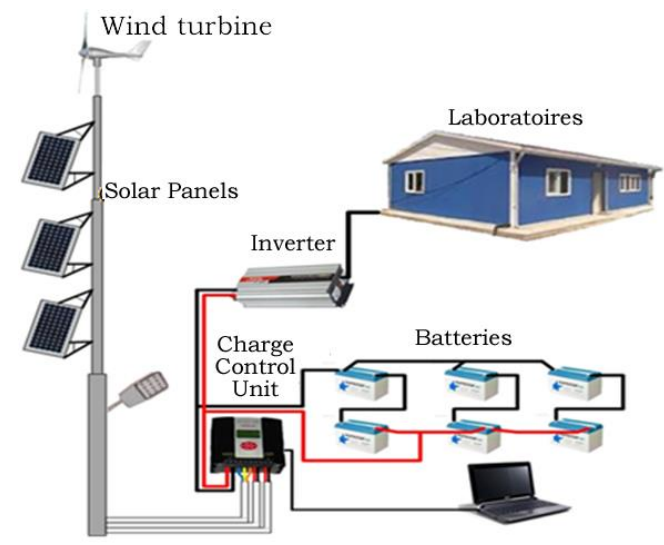

Fig 2. General view of the installed wind-solar hybrid power generation system [18]
Another important part of a hybrid power generation system is the charge controller. The low-voltage feature is enabled at $4 \mathrm{~V}$. That means, the systems goes on production when the wind turbine reaches the speed that can generate $4 \mathrm{~V}$ if the batteries are below $28.2 \mathrm{~V}$. This feature allows the turbine to produce energy even at low wind speed. The charge control unit has two D.C. outputs. The first output enables or disables D.C. depending on the light intensity over solar panels. The second one does the same thing but it can be set up to be disabling at any desire time. These features prevent unnecessary energy consumption related to LED fixture on outdoor lighting.

This is necessary to know the general consumption of illumination system in these two laboratories based on their weakly course schedule to analyze the efficiency of hybrid power generation system. Then it can be found how much of the electrical energy that is being produced by the hybrid power generation system. According to the obtained data, energy saving rate can be determined when the hybrid power generation system is in use. When we look at the entire months' production and consumption data as shown in Figure 3 , it has been seen that production of power is greater than the consumption except June. Due to failures that have occurred in the system, data could not be obtained within 15 days of June [18].

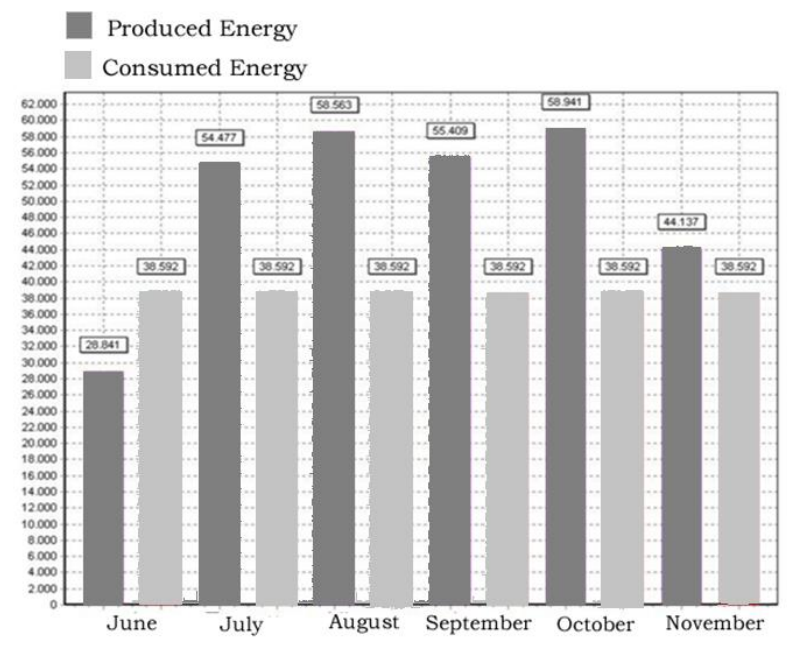

Fig 3. The total energy productions and consumptions by the months [18]

The difference between production and consumption can be determined by this comparison. The comparison in unit price which is $\$ 0.145$ can be seen in Table 2. Calculations shows that the amount of consumed electricity for general illumination of laboratory was $\$ 33,42$ for six months and the amount of produced electrical energy was $\$ 43,38$. As it can be seen on Table 3, the production of the hybrid power generation system has met the electrical energy consumed by the general illumination system with $\$ 9,94$ surplus. 
TABLE II

THE AMOUNT OF ENERGY SAVING BY THE USE OF HYBRID POWER GENERATION SYSTEM [18]

\begin{tabular}{|c|c|c|c|c|c|c|}
\hline Data & 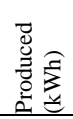 & 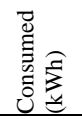 & 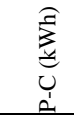 & 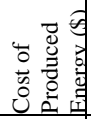 & 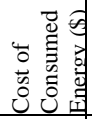 & 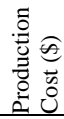 \\
\hline June & 28.84 & 38.592 & -9.75 & 4.16 & 5.57 & -1.40 \\
\hline July & 54.47 & 38.592 & 15.88 & 7.87 & 5.57 & 2.29 \\
\hline August & 58.56 & 38.592 & 19.97 & 8.45 & 5.57 & 2.88 \\
\hline September & 55.40 & 38.592 & 16.81 & 8.02 & 5.57 & 2.43 \\
\hline October & 58.94 & 38.592 & 20.34 & 8.51 & 5.57 & 2.94 \\
\hline November & 44.13 & 38.592 & 5.545 & 6.37 & 5.57 & 0.8 \\
\hline Total & 300.3 & 231.55 & 68.81 & 43.3 & 33.42 & 9.94 \\
\hline
\end{tabular}

The result of 6 months data shows that the solar-wind hybrid power generation system can produce more than enough electrical energy to illuminate entire two electrical laboratories. The numerical data express it clearly that this contributes in providing alternative energy source for consumers and also provides economical contribution to the country. By all accounts, it is also estimated that the system will amortize its cost within 7 or 8 years.

\section{CONCLUSIONS}

The usage of fossil fuel-based energy is not promising method because of environmental pollution, greenhouse effect, adverse effects on human health and natural vegetation. In parallel with the technological development, usage of renewable energy sources which are environmental friendly and inexpensive will be widespread. Particularly, it is accepted that solar and wind power will provide opportunity for individual energy production to use in both cities and rural areas within high potential. In modern cities, it is possible that individual energy production based on solar and wind will change urban architecture and energy policy radically.

In this context, solar and wind energy should be considered under subheading, researches and projects should be supported while environmental strategies are being determined. Primarily, streets and roads, parks and gardens, highways, traffic lamps, remote areas lighting systems should be expanded to use renewable alternative energies. It should be encouraged to use these systems in our country which have many examples all over the world.

\section{REFERENCES}

[1] D. Cristian D. Bica, "Photovoltaic Laboratory for Study of Renewable Solar Energy". In International 43th Universities Power Engineering Conference 2008, p 1-5, 2008.

[2] M. Bojic, 'Will Renewable Energy Save Our Planet?' In 3rh Global Conference, Power Control And Optimization, p 12-21, 2010.

[3] K.B. Varinca, M.T. Gonullu, "Solar Energy Potential in Turkey and Degree of use of this potential, A Survey on Prevalence and management", First National Solar and Hydrogen Energy Congress, Turkey, 2006.

[4] M.A. Batman, "A new method to increase the operational efficiency of solar cells for generating electricity". Istanbul technical University, Doctorate thesis, Turkey, 2001.

[5] V. Altın, "Electric production with solar system". Journal of Architects and Engineers, Vol. 33. pp. 28-31, 2004.
[6] S. Iscan, R. Karayel, Z.O. Ozcan, S. Gurleyen, "Solar Trackıng System (2-Way)". MKT2012, Project-Based Mechatronics Training Workshop, Çankırı, Turkey, 2012.

[7] S. Abdallah, OO. Badran, "Sun tracking system for productivity enhancement of solar stil". Elsevier, Desalination Vol. 220, pp. 669676, 2008.

[8] Why Solar and Wind Energy?, http://www.yesaenerji.com/, Date of access: 05.08.2014

[9] Renewable energy sources, megep.meb.gov.tr/, Date of access: 04.08.2014

[10] S. Oktik, "Solar Energy Generating Electricity from direct (photovoltaic) industry and LED", Lighting applications, Solar Energy Industries Association and Industry, 2013.

[11] E.M. Yegin, M.Z. Bilgin, Energy Efficiency of LED Street Lighting Fixtures for Use in Kocaeli region and Impact on Costs, Kocaeli University, Department of Electrical Engineering.

[12] G. Held, "Introduction to Light Emitting Diode Technology and Applications". ISBN 9781420076622 , CRC Pres, 2008.

[13] Grounding and Lightning Protection Solar Panels, http://www.guneshaber.net/, Date of access: 22.07.2015

[14] J.W. Twidell and A.D. Weir, "Renewable Energy Resources", E.\& F.N. Spon Ltd., London, New York, 1986.

[15] Y. Chen, Z. Liu, 'Distributed Intelligent City Street Lamp Monitoring and Control System Based on Wireless Communication chip nRF401', 2009 International Conference on Networks Security, Wireless Communications and Trusted Computing, DOI 10.1109/NSWCTC.2009.69, 2009.

[16] New Trends in Road and Street Lighting, http://www.elektrikport.com/, Date of access: 06.08.2014

[17] Solar sokak aydınlatma sistemleri, http://www.na-me.com.tr/, Date of access: 06.09.2014

[18] H.H. Oguz, "Installation of wind-photovoltaic power generation system and control of general illumination system with PIC 16F877 controller for efficient use of energy", Afyon Kocatepe University, Graduate School of Natural and Applied Sciences , Master Thesis, 2012.

\section{BIOGRAPHIES}

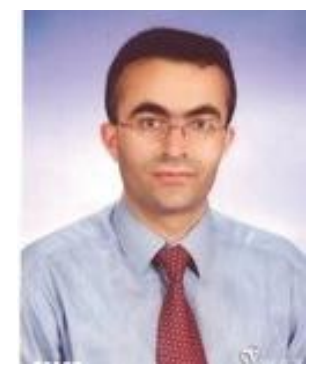

Yüksel OĞUZ, He was born in Afyon, Turkey, in 1971. He has received his B.Sc degree from the Marmara University, Faculty of Technical Education, Department of Electrical Education, Istanbul. After that, he has received his M.Sc and Ph.D. degrees in Electrical Education from the Marmara University, Institute for Graduate Studies in Pure and Applied Sciences, between 2000 and 2007, respectively. He is working as Associate Professor in the Electronic and Electronic Engineering Department at Afyon Kocatepe University. He mainly teaches and studies in education of control systems, automatic control applications, electrical machines, power generation systems and control, renewable energy, and intelligent control systems.

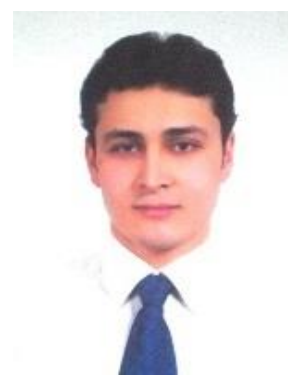

Mustafa ŞAHIN, He was born in Bursa, Turkey, in 1981. He has received his B.Sc degree from the Marmara University, Faculty of Technical Education, Department of Electrical Education. After that, he received the M.Sc. degree in 2010 and $\mathrm{Ph} . \mathrm{D}$. degree in 2014 respectively from Institute for Graduate Studies in Pure and Applied Sciences at Marmara University, TURKEY. He is currently working as Assistant Professor in Department of Electrical \& Electronics Engineering at Erzincan University. His research interests are artificial neural networks, illumination systems and renewable energy. 


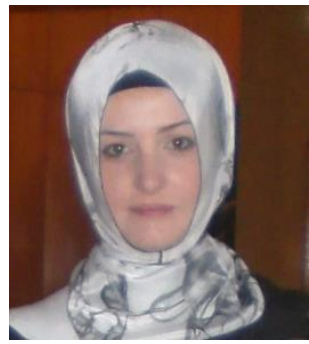

Elif ŞAHIN She was born in Istanbul, Turkey, in 1985. She has received B.Sc degree from the Sakarya University, Faculty of Arts and Science s, Department of Physics. Then she has received the B. Eng. in Medical Physics (Industrial Physi cs) from Istanbul Commerce University betwee n 2010 and 2012 respectively. Her research interests are nuclear physics, medical physics, lase rs and renewable energy.

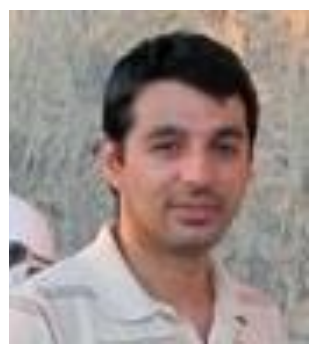

Yılmaz GÜVEN, He was born in Gaziantep, in 1981. He has received B.Sc degree from the Marmara University, Faculty of Technical Education, Department of Electrical Education. Then he received the M.Sc. degree in 2010 from the Institute for Graduate Studies in Pure and Applied Sciences at Marmara University, TURKEY. He is continuing his education for $\mathrm{Ph} . \mathrm{D}$. degree at the same institute. He is currently working as a lecturer in Vocational School at Kırklareli University. His research interests are automation systems, microcontrollers and electrical machinery. 